\title{
Distribution of piston compression ring pressure against the deformed cylinder wall
}

\begin{abstract}
The following study presents typical cylinder deformations that come up during engine assembly and operation and provides results of analysis of how these changes affect the operation of the compression ring. Special attention has been paid to the effect of cylinder diameter increase on the distribution of the circumferential wall pressure and the cause of light gaps formation has been explained.

The analyses presented in the following paper have been carried out using a computer program that has been formulated based on a compression ring mathematical model. Exemplary results of simulation have been obtained for a medium speed generator engine of a cylinder diameter of $0.48 \mathrm{~m}$.
\end{abstract}

Key words: marine combustion engine, piston ring, oil film, ring wall pressure

\section{Rozkład nacisku tlokowego pierścienia uszczelniającego na gładź zdeformowanego cylindra}

\begin{abstract}
W opracowaniu opisano typowe deformacje cylindra pojawiajace sie podczas montażu i eksploatacji silnika oraz przedstawiono wyniki analizy wpływu tych zmian na pracę pierścienia uszczelniającego. W szczególności omówiono wplyw wzrostu średnicy cylindra na rozkład obwodowego nacisku pierścienia oraz wyjaśniono przyczyny powstawania tzw. szczelin świetlnych.

Prezentowane w opracowaniu analizy przeprowadzono przy wykorzystaniu programu obliczeniowego powstałego na podstawie modelu matematycznego uszczelniajacego pierścienia tłokowego. Zaprezentowane w artykule przyktadowe wyniki symulacji uzyskano dla agregatowego silnika średnioobrotowego o średnicy cylindra równej 0,48 mm.
\end{abstract}

Słowa kluczowe: silnik okrętowy, pierścień tłokowy, film olejowy, rozkład nacisków pierścienia

\section{Introduction}

Even minor deformations of cylinder wall can cause a loss of light-tightness between the ring face and the cylinder liner influencing the tightness of the combustion chamber, deterioration of the engine parameters and increase in the wear of piston-cylinder assembly elements.

Deformations of cylinder could occur both at the stage of engine assembly and during its operation. Deformations which could occur during installation of the cylinder head or the cylinder liner are dependent to a considerable extent on the design of the elements and the materials. Figure 1 presents layouts of cylinder exemplary deformations caused by different ways the head is installed into the cylinder block. More examples of such deformations can be found in [1].

Nevertheless, the major changes in geometry and inner diameter of cylinder take place during engine operation. A typical profile of the liner (Fig. 2a) shows that its maximal wear occurs at the liner upper part where the first compression ring contacts the cylinder wall when the piston moves close to the TDC. This can be explained by the effect of high temperature and high wall pressure (curves of wear are very similar to the curves of temperature and pressure). Precise measurements of the cylinders show that this wear is more complicated, which could not be explained directly by the phenomena described by the hydrodynamic theory of lubrication.

It is generally believed that during engine operation the following factors most significantly affect the differentiation

\section{Wprowadzenie}

Nawet niewielkie zmiany kształtu cylindra mogą spowodować pojawienie się tzw. szczelin świetlnych pomiędzy powierzchniami ślizgowymi pierścienia i cylindra, wpływających na zmniejszenie szczelności komory spalania, pogorszenie parametrów pracy silnika oraz na wzrost zużycia elementów układu tłokowo-cylindrowego.

Odkształcenia cylindra mogą powstawać zarówno w fazie montażu silnika, jak i podczas jego eksploatacji. Do grupy odkształceń montażowych zalicza się deformacje powstałe podczas mocowania głowicy lub osadzania tulei w bloku cylindrowym, a na ich wielkość $i$ kształt istotny wpływ wywierają ich konstrukcja oraz materiały, z jakich wykonano te elementy. Na rysunku 1 pokazano szkice przedstawiające przykładowe odkształcenia cylindra, spowodowane odmiennym sposobem łączenia głowicy z blokiem cylindrowym. Więcej przykładów tego typu odkształceń można znaleźć w pracy [1].

Jednak największe zmiany geometrii i średnicy wewnętrznej cylindra zachodzą podczas eksploatacji silnika. Typowy profil eksploatowanej tulei (rys. 2a) wskazuje, że jej maksymalne zużycia pojawią się w górnej części, w obszarze styku pierwszego pierścienia uszczelniającego $\mathrm{z}$ gładzią cylindra $\mathrm{w}$ ZZ tłoka. Zjawisko to thumaczy się działaniem w tym obszarze wysokiej temperatury i występowaniem dużych nacisków pierścienia (potwierdzeniem tego spostrzeżenia jest to, że krzywe zużycia wykazują dużą zbieżność z krzywymi obrazującymi rozkłady tem- 
a)

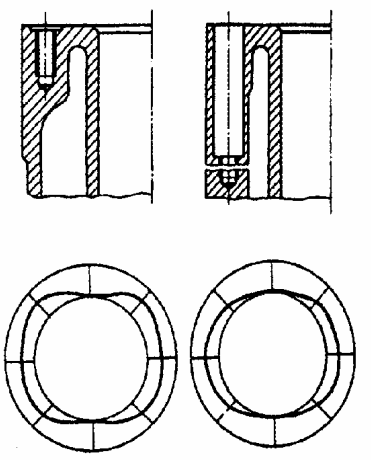

b)
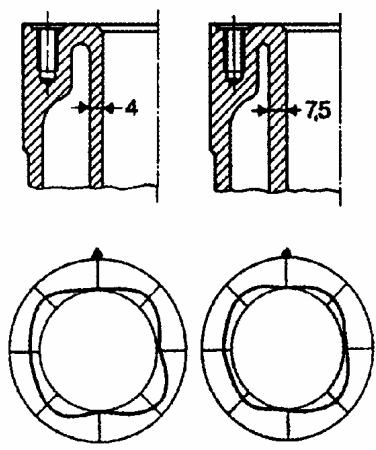

Fig. 1. Changes in deformations of cylinder wall working surface caused by: a) different fixing of cylinder head, b) different thickness of cylinder wall [1]

Rys. 1. Zmiany w obrazie odksztatcenia powierzchni ślizgowej cylindra spowodowane: a-odmiennym sposobem osadzenia śrub mocujacych głowicę, b-różna grubościa ścianek cylindra [1]

of the wear (circumferential in particular) of the cylinder liner [5]:

- design of the lubrication system and the use of different lube oils,

- different operating conditions of some elements within the piston-cylinder group caused by faulty assembly and adjustment of the engine,

- different operating conditions of a group of cylinders, e.g. common turbocharger,

- individual constructional, material, technologic and assembly differences in cylinders.

The lubrication system as the cause of irregular wear, mentioned in the first place, comes from the fact that a certain volume of lube oil is necessary for a formation of continuous oil film between the working surfaces. Opposite to engines of lower power output, where the working surfaces of the liner are lubricated with the oil mist, marine engines oil is supplied directly to the spots of the cylinder surface. In earlier solutions the oil was supplied by lubricating nozzles positioned along the cylinder circumference and was distributed by special lubricating grooves. Such a way of lubricating was highly inefficient.

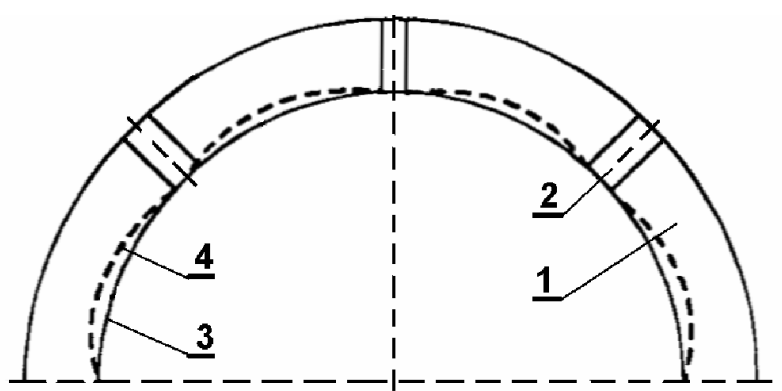

Fig. 3. "Clover leaf" pattern of cylinder surface wear: 1 - cylinder liner, 2 - lubricating nozzle, 3 - ideal profile of the cylinder surface, 4 - profile of the worn cylinder surface [10]

Rys. 3. Zużycie gładzi cylindra w kształcie , liścia koniczynki”:

1 - tuleja cylindrowa, 2 - króciec smarny, 3-idealny profil gładzi cylindra, 4-zużty profil gładzi [10]

a)

b)
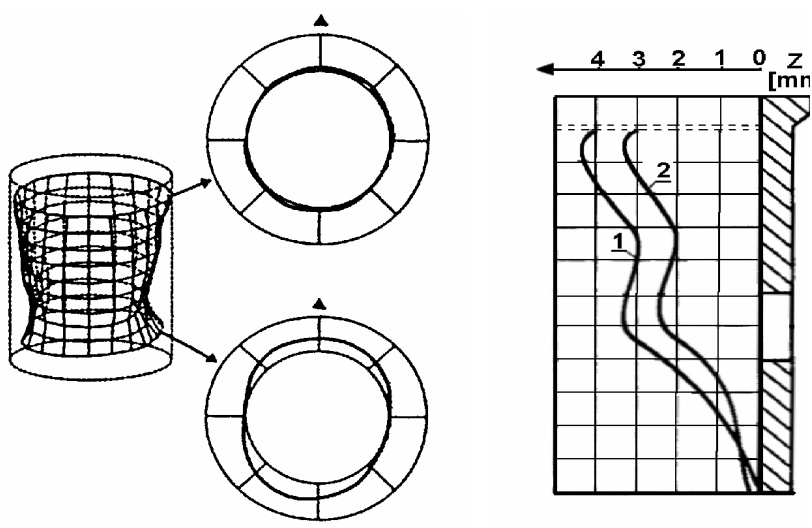

Fig. 2. A sketch of the deformed cylinder (a) profile of the working surface measured in two perpendicular planes of the cylinder cross section (b)

Rys. 2. Szkic odksztatconego cylindra (a) oraz profil powierzchni ślizgowej mierzony $w$ dwóch wzajemnie prostopadlych płaszczyznach przekroju cylindra (b)

peratury i nacisku). Dokładne pomiary eksploatowanych tulei cylindrowych wykazują jednak, że zużycie to ma bardziej złożoną postać, niedającą się bezpośrednio wyjaśnić zjawiskami opisanymi przez hydrodynamiczną teorią smarowania.

Uważa się, że najważniejszy wpływ na zróżnicowanie zużycia (szczególnie obwodowego) gładzi cylindra podczas eksploatacji silnika okrętowego mają [5]:

- konstrukcja układu smarowania i stosowanie różnych gatunków olejów smarowych,

- odmienne warunki pracy niektórych elementów układu tłokowo-cylindrowego spowodowane różnego rodzaju błędami powstającymi podczas montażu i regulacji silnika,

- odmienne warunki współpracy dla pewnej grupy cylindrów (np. wspólna turbosprężarka),

- indywidualne różnice konstrukcyjne, materiałowe, technologiczne i montażowe poszczególnych cylindrów.

Wymienienie na pierwszym miejscu jako przyczyny nierównomiernego zużycia układu smarowania wynika z faktu, że do utworzenia ciągłego filmu olejowego pomiędzy współpracującymi powierzchniami wymagana jest odpowiednia ilość oleju smarowego. W odróżnieniu od silników mniejszej mocy, w których powierzchnie cylindrów są smarowane mgłą olejową, w silnikach okrętowych olej doprowadzany jest punktowo na gładź cylindra. W starszych systemach olej dostawał się na gładź cylindra za pomocą tzw. króćców smarnych, rozmieszczonych na obwodzie cylindra, a następnie był rozprowadzany obwodowo dzięki istnieniu specjalnych rowków smarowych. Taki sposób smarowania gładzi był mało skuteczny. Pomimo stosowania bardzo dużych dawek oleju pojawiały się obszary, w których dochodziło do zrywania ciągłości filmu olejowego i nadmiernego zużycia gładzi. Spostrzeżenie to potwierdzają wyniki pomiarów eksploatowanych tulei (rys. 3). W obszarach gładzi położonych między punktami smarowymi wystę- 
a)

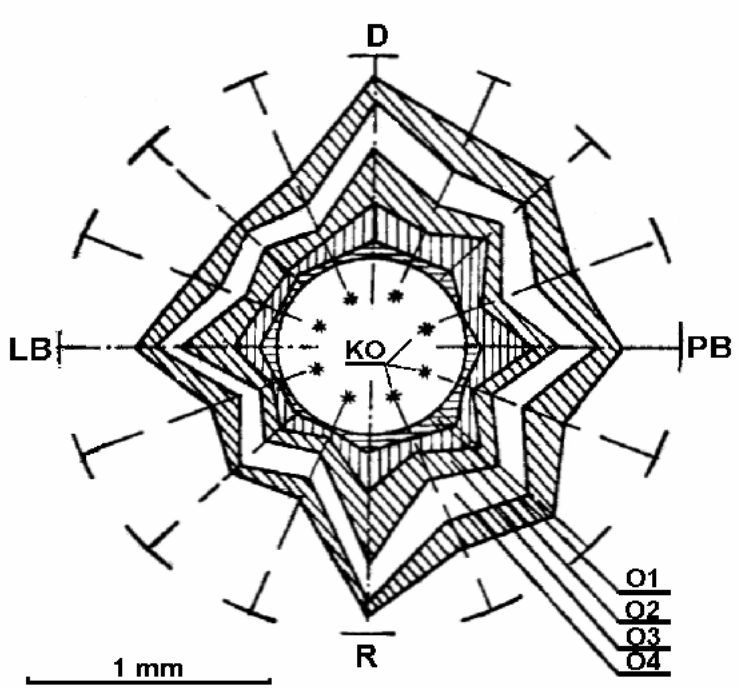

b)

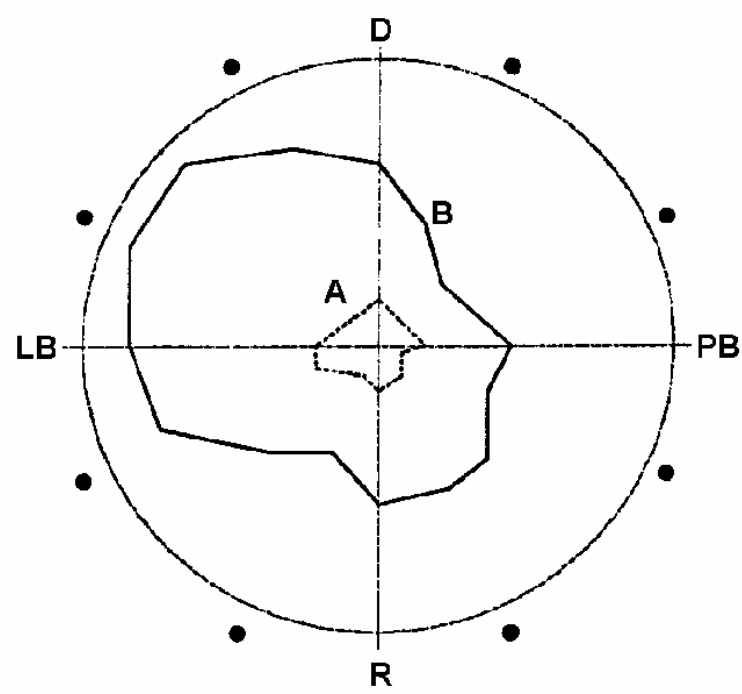

Fig. 4. Diagrams of cylinder liner wear: $a-$ depending on the lubricating oil TBN $(\mathrm{O} 1-\mathrm{O} 4), \mathrm{b}-$ depending on the period of operation with a faulty injector: A - after 2000 hours, B - after 5000 hours, D - bow, R - stern, LB and PB port and starboard, respectively, KO - lubricating oil nozzle [9, 10]

Rys. 4. Wykresy zużycia gładzi tulei cylindrowej: $a-w$ zależności od zasadowości zastosowanego oleju smarowego (O1 - O4), b-w zależności od czasu pracy silnika przy wadliwie pracujacym wtryskiwaczu: $A$ - po 2000 h pracy, $B$ - po 5000 h pracy, D-dziób, $R$ - rufa, LB, PB - lewa i prawa burta, $K O$ - króćce olejowe [9, 10]

In spite of using much oil in some regions lubricating was inadequate which led to oil film ruptures and liner excessive wear. This observation is confirmed by the results of measurements of the liners (Fig. 3). An increased wear called "clover leafing" occurs at regions of liner located between the lubricating spots.

In order to avoid such unfavorable incidents in modern lubrication systems of marine engines (e.g. the PLS system) oil is splashed over cylinder surface be a number of jets creating an almost evenly distributed layer.

Besides uneven lubrication excessive wear of marine engine cylinder wall can be caused by other reasons. For example, Fig. 4a shows a form of surface wear much higher along the bow-stern axis than along the port-starboard axis (difference is almost 50\%) which is explained by the deflection of the crankshaft or engine foundation frame. On the other hand, Fig. $4 \mathrm{~b}$ shows another case of excessive wear caused by a faulty injector.

The measurements of a partially worn cylinder allow an evaluation whether the boundary values have been exceeded, i.e. maximum admissible diameter and deviation from true circle (measured in each measuring planes) and cylindricality (measured in the planes crossing the measurement directions and the axis of the liner). The graph presented in Fig. 5 shows the approximate values of admissible cylinder wear and oval deformation vs. cylinder diameter for low speed marine engines, developed according to the data provided by [9].

The increase in the cylinder diameter and the changes in its form occurring during engine operation result in a decrease in the ring wall pressure. In order to define the effect of such a drop in the ring wall pressure on the parameters of oil film formed over the cylinder surface certain puje zwiększone zużycie, nazywane zużyciem „w liść koniczyny" (clover leafing).

W celu uniknięcia tego niekorzystnego zjawiska w najnowszych systemach smarowania silników okrętowych (np. w systemie PLS) olej jest natryskiwany na gładź cylindra wieloma strumieniami, tworząc w miarę równomiernie rozłożoną warstwę.

Poza nierównomiernym smarowaniem w silnikach okrętowych dochodzi również do nadmiernego zużycia gładzi spowodowanego innymi przyczynami. Przykładowo, na rys. 4a pokazano kształt zużycie gładzi o wartościach znacznie większych w osi dziób statku-rufa niż w osi lewa burta-prawa burta (różnica dochodzi do 50\%), co badacze tłumaczą ugięciem wału korbowego lub ramy

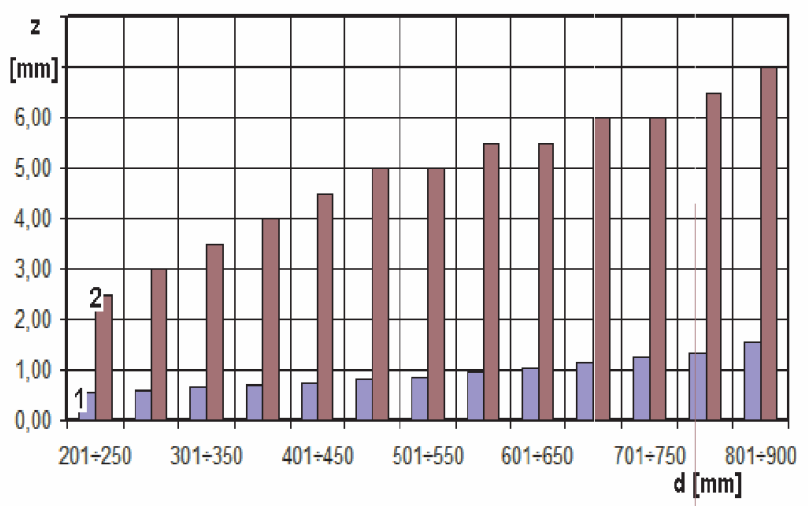

Fig. 5. Approximate values of boundary ovality (1) and boundary wear (2) of low speed marine engine liners depending on their diameter [5] Rys. 5. Orientacyjne wartości granicznej owalności (1) i granicznego zużycia (2) tulei silników okrętowych wolnoobrotowych $w$ zależności od ich średnicy [5] 
investigations should be performed. These investigations the presented paper are substituted by simulations using a mathematical model of the piston ring because of specific measuring difficulties.

\section{Investigations of the change in the ring wall pressure inside the cylinder of an enlarged diameter}

A method of determination of the ring elastic wall pressure against an ideally cylindrical and deformed cylinder liner was proposed by Iskra [1]. The mathematical model formulated according to this method, eventually developed and implemented by the authors was described in [6-8]. It is worth mentioning that the essence of this method lies in the substitution of the real ring with a model one, consisting of a number of articulated rigid straight-line sections (Fig. 6). Moreover, it has been assumed that bending of a substitute ring occurs only at joints and their substitutive stiffness corresponds to the stiffness of a real ring distributed along the entire circumference.

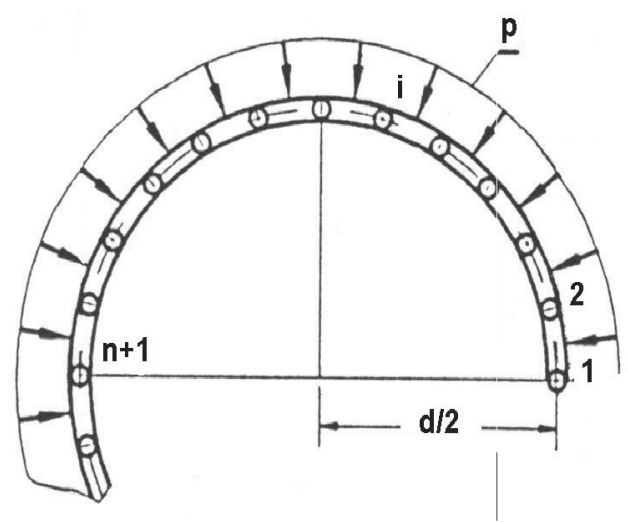

Fig. 6. Schematics of the substitutive model of a piston ring [1] Rys. 6. Schemat modelu zastępczego pierścienia ttokowego [1]

The above described computer program developed by the authors has been applied to the computations aiming at the principal goal, i.e. at a determination of the shape change and circumferential distribution of the wall pressure inside the cylinder of different wear level. Additionally, it has been assumed that:

- the ring touches the wall along the entire circumference with the preliminary pressure in new, ideally cylindrical liner,

- despite the increase in the diameter, the cylinder cross section remains circular,

- independently of the cylinder diameter, an increased ratio ring contacts the liner opposite the ring gap,

- the surfaces of the ring face and the cylinder are ideally smooth, i.e. the micro roughness is not taken into account in the computations,

- the working surfaces of the ring and the cylinder are not separated with oil film,

- the external forces acting on the ring (e.g. gas forces) are not taken into consideration. fundamentowej silnika. Z kolei za przyczynę powstania nadmiernego zużycia gładzi o kształcie pokazanym na rys. 4b uważa się wadliwie pracujący wtryskiwacz.

Pomiary geometrii eksploatowanej tulei pozwalają ocenić, czy nie zostały przekroczone wartości graniczne, tj. maksymalnie dopuszczalna średnica oraz odchyłki okrągłości (mierzone w każdej z płaszczyzn pomiarowych) i odchyłki walcowości (mierzone w płaszczyznach przechodzących przez kierunki pomiarów i oś tulei). $\mathrm{Na}$ wykresie rys. 5 pokazano opracowane na podstawie danych zestawionych w pracy [9] orientacyjne wartości granicznego zużycia i granicznej owalności tulei dla silników okrętowych wolnoobrotowych w zależności od średnicy cylindra.

Wzrost średnicy i zmiany kształtu cylindra pojawiające się w czasie eksploatacji silnika powodują rozprężanie się pierścienia i spadek jego nacisku na gładź. Dla określenia wpływu zmian wartości tego nacisku na parametry tworzącego się na gładzi cylindra filmu olejowego konieczne jest wykonanie badań, które, ze względu na problemy pomiarowe, w tym opracowaniu zostały zaplanowane jako badania symulacyjne realizowane przy wykorzystaniu modelu matematycznego pierścienia.

\section{Badania zmiany nacisku sprężystego pierścienia w cylindrze o powiększonej średnicy}

Metodę wyznaczenia rozkładu nacisku sprężystego pierścienia na ścianki idealnie okrągłego oraz zdeformowanego cylindra zaprezentował A. Iskra [1]. Opracowany na podstawie tej metody model matematyczny, wykorzystany i rozbudowany przez autorów niniejszego opracowania, opisano m.in. w pracach [6-8]. W tym miejscu należy jedynie wspomnieć, że jej istota polega na zastąpieniu pierścienia rzeczywistego jego modelem obliczeniowym, składającym się z pewnej liczby sztywnych odcinków prostoliniowych połączonych przegubami (rys. 6). Założono, że zginanie pierścienia zastępczego jest możliwe tylko w przegubach, przy czym ich zastępcza sztywność odpowiada rzeczywistej sztywności rozproszonej na całym obwodzie pierścienia.

Do realizacji obliczeń, których podstawowym celem jest określenie zmiany kształtu oraz obwodowego rozkładu nacisku pierścienia osadzonego wewnątrz cylindra o różnym stopniu zużycia gładzi, wykorzystano program obliczeniowy opracowany przez Autorów na podstawie wcześniej wspomnianych założeń. Dodatkowo przyjęto, że:

- w nowym, idealnie okrągłym cylindrze pierścień całym obwodem przywiera do gładzi z określonym wstępnie naciskiem,

- pomimo wzrostu średnicy przekrój cylindra pozostaje nadal okręgiem,

- niezależnie od wielkości wzrostu średnicy cylindra pierścień zawsze przywiera do gładzi cylindra w punkcie położonym naprzeciw zamka pierścienia,

- powierzchnie pierścienia i cylindra są idealnie gładkie, tzn. w obliczeniach nie uwzględnia się mikronierówności na powierzchniach współpracy, 
To begin the model inves- a) tigation one should know the technical data of the ring and the liner. For exemplary calculations that will be presented later the assumed ring is characterized by the following data of a real ring used in medium speed engine L48/60CR type [2]:

- ring radius $r_{p}=0.24 \mathrm{~m}$, (equal to $\mathrm{R}_{\mathrm{c}}$ - the radius of a new cylinder),

- axial height $\mathrm{h}_{\mathrm{p}}=15 \mathrm{~mm}$,

- radial thickness $\mathrm{g}_{\mathrm{p}}=16 \mathrm{~mm}$,

- modulus of elasticity $\mathrm{E}=$ $=1.2 \cdot 10^{5} \mathrm{MPa}$.

The test have been carried out for three cases of pressure circumference distribution, i.e. for balanced distribution, increased and reduced pressure close to the free gap (however, the average value of the pressure remained constant and was $\mathrm{p}_{\mathrm{s}}=$ $0.063 \mathrm{MPa}$ which corresponds to the catalogue value for the ring of this kind). The ring circumferential pressure distribution has been presented as the sum of 10 Fourier harmonics. The maximum wear of the liner surface was limited to $Z=0.5 \mathrm{~mm}$.

\section{The results of the simulation tests and their analysis}

The results of the tests carried out, after preliminary processing, have been presented in Figs. 8, 9 and 10.

The shape analysis of a ring installed in the liner of a growing diameter proved that the ring contacts the cylinder surface along the whole circumference only in a new liner (its wear $\mathrm{Z}=0$ ). Along with the increase in the liner wear (which is synonymous to the increase in the liner diameter) the expanding ring presses against the cylinder surface less intensely (Fig. 8a).

a)

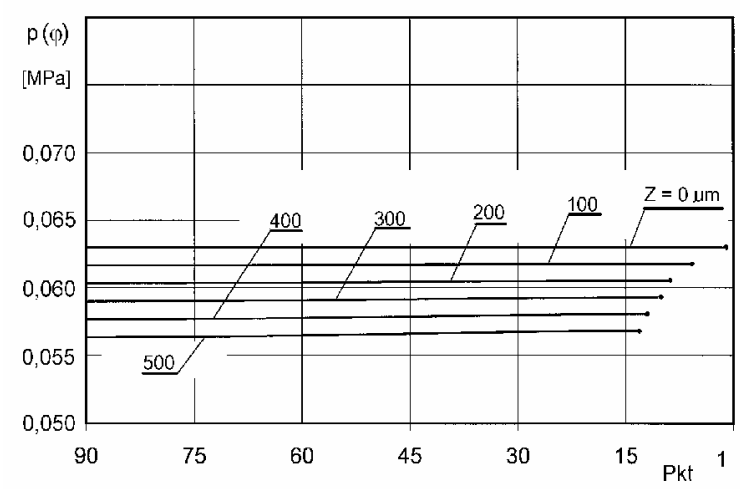

b)

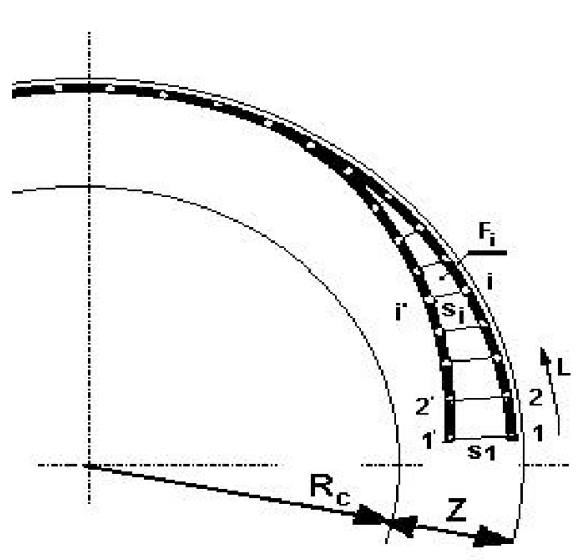

Fig. 7. A sketch of a piston compression ring (a) and an approximate shape of the ring inside the cylinder of and increased diameter (b)

acego pierścienia tłokowego (a) oraz orientacyjny ksztalt przyjmowany przez pierścień w cylindrze towarzyszacy wzrostowi jego średnicy (b)

- powierzchnie współpracy pierścienia i cylindra nie są rozdzielone warstwą oleju,

- w czasie obliczeń nie uwzględnia się sił zewnętrznych działających na pierścień (np. sił gazowych).

Rozpoczęcie badań modelowych wymaga dysponowania informacjami o parametrach pierścienia i cylindra. Do przykładowych, prezentowanych dalej, obliczeń przyjęto pierścień uszczelniający odpowiadający parametrom pierścienia silnika średnioobrotowego L48/60CR o następujących parametrach (pierścień o identycznych parametrach wykorzystano podczas badań opisanych w pracy [2]):

- promień pierścienia $r_{p}=0,24 \mathrm{~m}$, (równy promieniowi nowego cylindra $\mathrm{R}_{\mathrm{c}}$ )

- wysokość osiowa $\mathrm{h}_{\mathrm{p}}=15 \mathrm{~mm}$

- grubość promieniowa $\mathrm{g}_{\mathrm{p}}=16 \mathrm{~mm}$

- moduł sprężystości $\mathrm{E}=1,2 \cdot 10^{5} \mathrm{MPa}$

Badania przeprowadzono dla trzech przypadków obwodowego rozkładu nacisków, tzn. rozkładu zrównoważonego,

b)

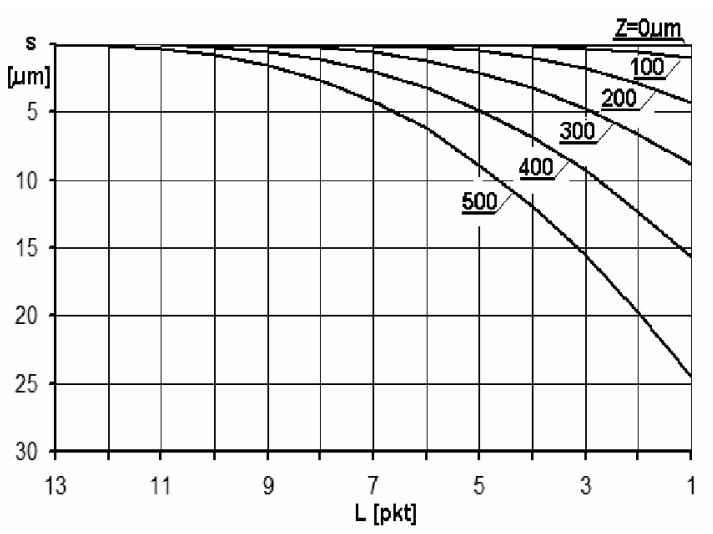

Fig. 8. Variations in (a) ring circumferential pressure $p(\varphi)$ and (b) slit wideness s dependent on liner surface wear Z; constant pressure distribution: $\mathrm{p}_{\mathrm{s}}=0.063 \mathrm{MPa}, \mathrm{p}_{\text {zam }}=0.063 \mathrm{MPa}$

Rys. 8. Zmiany nacisku obwodowego p ( $\varphi$ ) pierścienia (a) oraz szerokości s szczeliny (b) w zależności od zużycia Z gładzi cylindra; rozkład nacisków staty: $p_{s}=0,063 \mathrm{MPa}, p_{\text {zam }}=0,063 \mathrm{MPa}$ 
a)

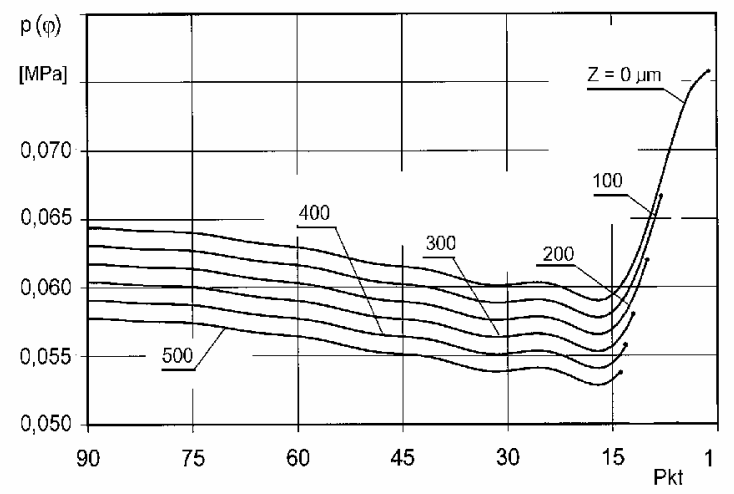

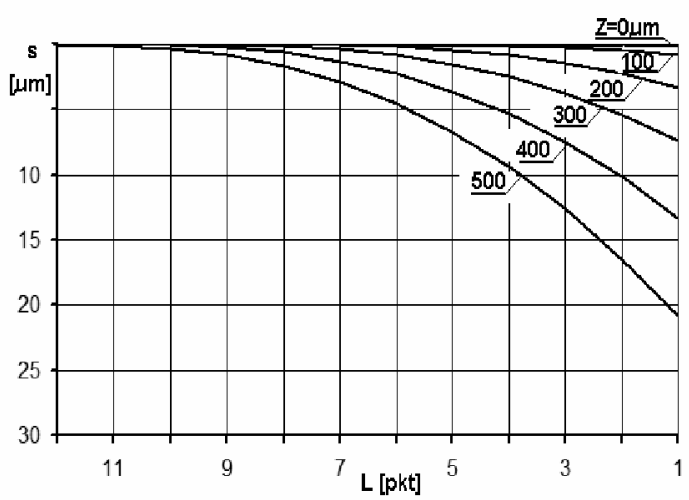

Fig. 9. Variations in (a) ring circumferential pressure $p(\varphi)$ and (b) slit wideness s dependent on liner surface wear Z; increased pressure distribution in the vicinity of the ring gap: $\mathrm{p}_{\mathrm{s}}=0.063 \mathrm{MPa}, \mathrm{p}_{\text {zam }}=0.076 \mathrm{MPa}$

Rys. 9. Zmiany nacisku obwodowego p ( $\varphi$ ) pierścienia (a) oraz szerokości s szczeliny (b) w zależności od zużycia Z gładzi cylindra; rozkład nacisków zwiększony w obszarze zamka: $p_{s}=0,063 \mathrm{MPa}, p_{\text {zam }}=0,076 \mathrm{MPa}$

At the same time the area of ring to wall contact diminishes (Fig. 8b) which results from the ring ends drifting apart (as shown in Fig. 7b). This phenomenon leads to a loss of light tightness which increases along with the cylinder wear (Fig. 11).

Piston ring designers are familiar with the drop in the ring wall pressure within the area of free gap, which is caused by different deformations of liners (thermal, mechanical and relative to wear). In order to prevent the consequences of this phenomenon (increase in the cylinder blow-bys) new rings exert a higher pressure in this region already at the design stage. On the other hand, in engines where the ring works with scavenging ports (two-stroke engines) this pressure should be reduced to avoid the ring ends breakoffs. To evaluate the effect of increased or reduced ring wall pressure $\left(\mathrm{p}_{\mathrm{zam}}\right)$ in the region of free gap on the light tightness computations were carried out and results are presented in Figs. 9 and 10.

A drop in the ring wall pressure, evenly distributed along the ring circumference is observed and it is the quickest for a unloaded ring (Fig. 11).

a)

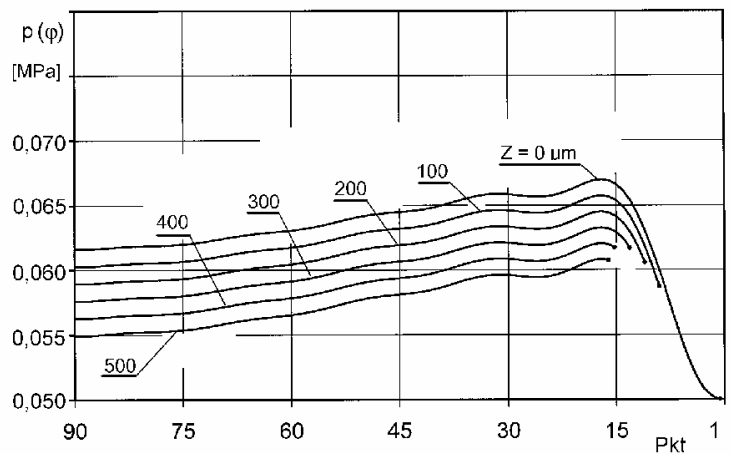

a także powiększonego i pomniejszonego w obszarze zamka (jednak we wszystkich przypadkach średnia wartość nacisku pozostawała stała $\mathrm{i}$ wynosiła $\mathrm{p}_{\mathrm{s}}=0,063 \mathrm{MPa}$, co odpowiada wartości katalogowej dla tego pierścienia). Obwodowy rozkład nacisków pierścienia przedstawiono jako sumę 10 harmonik rozkładu Fouriera. Maksymalne zużycie gładzi cylindra ograniczono do wartości $Z=0,5 \mathrm{~mm}$.

\section{Wyniki badań symulacyjnych i ich analiza}

Ważniejsze wyniki przeprowadzonych badań, już po wstępnym opracowaniu, przedstawiono na wykresach na rys. 8,9 i 10 .

Analiza kształtu pierścienia osadzonego w cylindrze o coraz większej średnicy wykazała, że tylko w nowym cylindrze (dla którego zużycie $Z=0 \mu \mathrm{m}$ ) pierścień całym obwodem przylega do gładzi cylindra. Wraz ze wzrostem zużycia gładzi (co jest równoznaczne ze wzrostem promienia cylindra) rozprężający się pierścień coraz słabiej naciska na gładź cylindra (rys. 8a). Jednocześnie obszar jego kontaktu z gładzią ulega zmniejszeniu (rys. 8b), co jest związane $\mathrm{z}$ oddalaniem się

b)

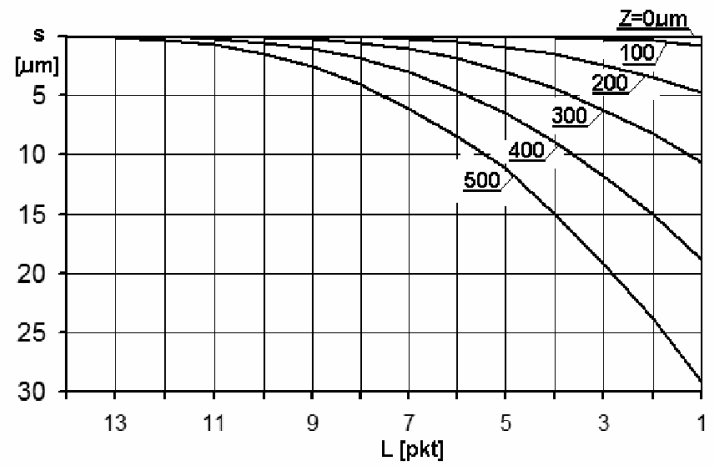

Fig. 10. Variations in (a) ring circumferential pressure $\mathrm{p}(\varphi)$ and (b) slit wideness s dependent on liner surface wear Z; reduced pressure distribution in the vicinity of the ring gap: $\mathrm{p}_{\mathrm{s}}=0.063 \mathrm{MPa}, \mathrm{p}_{\text {zam }}=0.050 \mathrm{MPa}$

Rys. 10. Zmiany nacisku obwodowego p(f) pierścienia (a) oraz szerokości s szczeliny (b) w zależności od zużycia Z gładzi cylindra; rozkład nacisków zmniejszony w obszarze zamka: $p_{s}=0,063 \mathrm{MPa}, p_{\text {zam }}=0,050 \mathrm{MPa}$ 


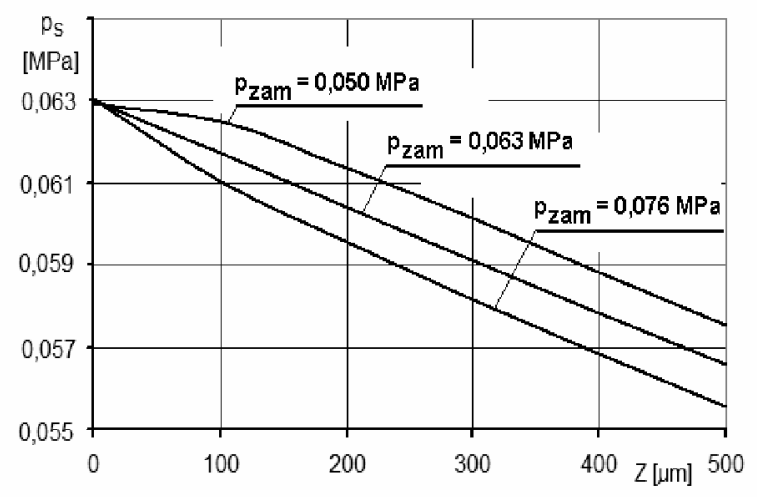

Fig. 11. Drop in the ring average pressure along with the wear of the cylinder surface for various types of pressure distribution in the vicinity of the gap

Rys. 11. Spadek średniego nacisku pierścienia wraz ze zużyciem gładzi cylindra dla różnych rodzajów rozkładu nacisku w obszarze zamka

The light tightness loosens when the wall pressure drops. To evaluate this quantitatively the relation between the $\mathrm{Z}$ liner wear and $\mathrm{F}$ area of light slit should be determined. One can conclude from the courses in Fig. 12 that the increase in the slit area is most rapid for an unloaded ring.

The results presented earlier have been obtained in a course of tests carried out using mathematical models, developed using simplifying assumptions adopted earlier. It has been assumed that calculations concern a ring installed on a piston of unfired engine, which leads to a lack of gas forces and oil film.

The basic task for the oil film is the separation of the working surfaces of the ring and the liner and the oil film thickness depends on a number of parameters connected with the geometry of the working elements, the working conditions as well as the properties of the lubricating oil. The exemplary courses of the oil film thickness have been calculated for the first compression ring of a medium speed engine. The acquired courses of the oil film thickness (Fig. 13) are comparable with the thickness of the

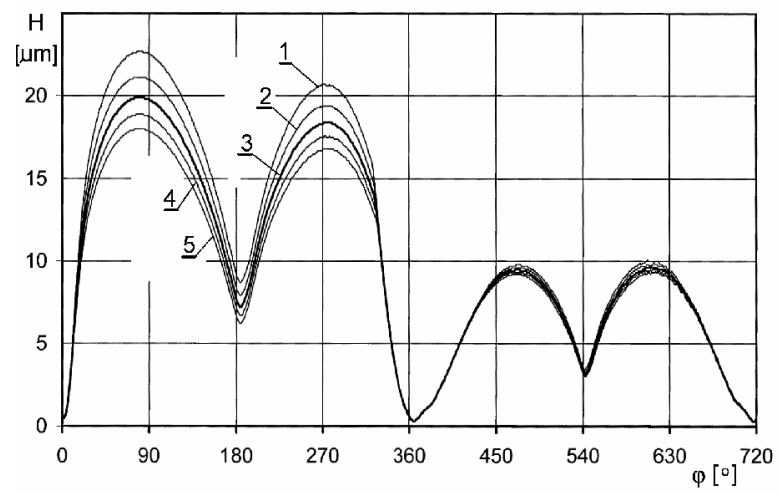

Fig. 13. Exemplary distribution of oil film thickness set for the first compression ring

Rys. 13. Przykładowy rozkład grubości filmu olejowego wyznaczony dla pierwszego pierścienia uszczelniajacego

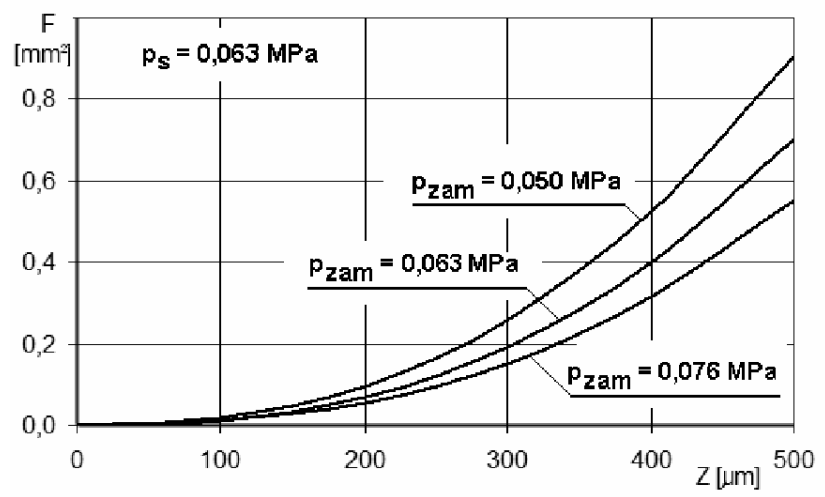

Fig. 12. Variations in light slit area F accompanying the cylinder surface wear $\mathrm{Z}$ for three types of pressure distribution in the vicinity of the gap: 1 - increased, 2 - even and 3 - reduced one

Rys. 12. Zmiany pola powierzchni F szczeliny świetlnej towarzyszace zużyciu $Z$ gładzi cylindra dla trzech rodzajów rozkładu nacisków w obszarze zamka: typów nacisku pierścienia: 1-zwiększonego, 2 -równomiernego, 3 -zmniejszonego

końców pierścienia od gładzi cylindra (w sposób zbliżony do pokazanego na rys. 7b). Efektem tego zjawiska jest powstawanie tzw. szczeliny świetlnej, której wymiary powiększają się wraz ze wzrostem zużycia cylindra (rys. 11).

Zjawisko spadku nacisku w obszarze zamka, spowodowane różnego typu deformacjami cylindra (termicznymi i mechanicznymi oraz związanymi ze zużyciem), znane jest konstruktorom pierścieni tłokowych. W celu zapobieżenia skutkom tego zjawiska (w tym przede wszystkim wzrostowi przedmuchów gazów do przestrzeni podtłokowej), już w fazie konstruowania w tym właśnie obszarze nadaje się pierścieniowi zwiększony nacisk. Z kolei w silnikach, w których pierścień współpracuje z cylindrami z oknami przepłukującymi (silniki dwusuwowe) zmniejsza się ten nacisk w celu zapobieżenia zahaczaniu końców pierścienia o krawędzie okien. W celu oceny wpływu zwiększonego i zmniejszonego nacisku pierścienia w obszarze zamka $\left(\mathrm{p}_{\text {zam }}\right)$ na wielkość i kształt szczeliny świetlnej, wykonano obliczenia, których wyniki zestawiono na wykresach na rys. 9 i 10 .

Zwiększeniu średnicy cylindra towarzyszy spadek nacisku pierścienia, równomierny na całym obszarze kontaktu pierścienia z gładzią cylindra, przy czym jest on najszybszy dla pierścienia odciążonego (rys. 11).

Zmniejszaniu się nacisku towarzyszy wzrost wielkości szczeliny świetlnej. Do ilościowej oceny tego zjawiska zbadano zależność pomiędzy powierzchnią szczeliny świetlnej F a zużyciem gładzi Z. Z analizy widocznych na rys. 12 przebiegów wynika, że wzrost powierzchni szczeliny następuje najszybciej dla pierścienia odciążonego.

Przedstawione wyżej wyniki uzyskano podczas badań realizowanych przy wykorzystaniu modeli matematycznych, opracowanych przy uwzględnieniu poczynionych wcześniej założeń upraszczających. Przyjęto m.in., że obliczenia dotyczą pierścienia osadzonego na tłoku niepracującego silnika, czego konsekwencją jest brak sił gazowych oraz filmu olejowego. 
light slit, which means that those slits can be partially or fully filled with oil during the engine operation. This leads to the increase in the circumferential region of the ring load transmission and the reduction in the exhaust blow-by.

\section{Conclusions}

The research on the phenomena accompanying the ring operation on a running IC engine shows that the ring wall pressure caused by the gas pressure sometimes distinctly exceeds the pressure connected with the ring's own elasticity. This means that momentary distributions of ring wall pressure could differ considerably from those presented in this paper. In order to carry out at least approximate evaluation of the effect of the ring elastic pressure fluctuations on the course of the oil film thickness test were carried out for selected values of the ring elastic pressure. The obtained results confirmed earlier observations (Fig. 13). The most considerable effect of the changes in the ring elastic pressure is visible within the regions where the ring speed is the highest and this effect is negligible in the vicinity of TDC (region of the strongest gas forces).

Paper reviewed/Artykut recenzowany
Podstawowym zadaniem filmu olejowego jest rozdzielenie powierzchni współpracy pierścienia i cylindra, a jego grubość zależy od wielu parametrów, związanych z geometrią współpracujących elementów, warunkami ich współpracy, a także z właściwościami oleju smarowego. Przykładowe przebiegi grubości filmu olejowego wyznaczono dla silnika średnioobrotowego, dla przypadku pracy tylko pierwszego pierścienia uszczelniającego. Uzyskane przebiegi wartości grubości filmu olejowego (rys. 13) są porównywalne z wartościami grubości szczeliny świetlnej, co oznacza, że podczas pracy w silniku mogą one być całkowicie lub częściowo wypełnione olejem. Efektem tego zjawiska będzie wzrost obwodowego obszaru przenoszenia obciążenia pierścienia oraz zmniejszenie przedmuchu gazów spalinowych.

\section{Podsumowanie}

Badanie zjawisk towarzyszących pracy pierścienia $\mathrm{w}$ silniku spalinowym wskazuje, że nacisk pierścienia, wywołany działaniem ciśnienia gazów, w niektórych obszarach drogi pierścienia znacznie przekracza nacisk wynikający ze sprężystości własnej pierścienia. W efekcie chwilowe rozkłady nacisków pierścienia na gładź będą się znacznie różnić od prezentowanych w tym artykule. W celu chociaż przybliżonej oceny wpływu zmiany nacisku własnego pierścienia na przebiegi grubości filmu olejowego wykonano obliczenia kontrolne dla wybranych wartości nacisku własnego pierścienia. Wyniki badań potwierdziły wcześniejsze spostrzeżenia (rys. 13). Największy wpływ zmian nacisku własnego pierścienia jest widoczny w obszarach największej prędkości przemieszczania się pierścienia, przy czym w obszarach działania największych sił gazowych (obszar ZZ) wpływ ten jest pomijalnie mały.

\section{Bibliography/Literatura}

[1] Iskra A.: Studium konstrukcji i funkcjonalności pierścieni w grupie tłokowo-cylindrowej. Wydawnictwo PP, Poznań 1996.

[2] Marine Engine Programme - MAN B\&W, informator, 2008.

[3] Merkisz J.: Zużycie oleju w szybkoobrotowych silnikach spalinowych, Wydawnictwo Politechniki Poznańskiej, Poznań 1994.

[4] Piston Ring Manual. Published by Goetze.

[5] Piaseczny L.: Technologia naprawy okrętowych silników spalinowych. Wydawnictwo Morskie, Gdańsk 1992.

Wojciech Serdecki, DSc., DEng. - Professor in the Faculty of Mechanical Engineering at Poznan University of Technology.

Dr hab. inż. Wojciech Serdecki - profesor na Wydziale Maszyn Roboczych i Transportu Politechniki Poznańskiej.

e-mail: wojciech.serdecki@put.poznan.pl
[6] Serdecki W.: Badania współpracy elementów układu tłokowocylindrowego silnika spalinowego. Wydawnictwo Politechniki Poznańskiej, Poznań 2002.

[7] Serdecki W.: Wpływ zmian nacisku sprężystego pierścienia tłokowego na parametry filmu olejowego, Kones 2002.

[8] Serdecki W., Krzymień P.: Compression rings of low-speed high power engines. Journal of Kones, Warsaw 2010.

[9] Włodarski J.K.: Zużycie i smarowanie maszyn okrętowych. Wydawnictwo Morskie, Gdańsk 1979.

[10] Włodarski J.K.: Podstawy eksploatacji maszyn okrętowych. Tarcie i zużycie. Akademia Morska, Gdynia 2006.
Piotr Krzymień, DEng. - doctor in the Faculty of Mechanical Engineering at Poznan University of Technology.

Dr inż. Piotr Krzymień - adiunkt na Wydziale Maszyn Roboczych i Transportu Politechniki Poznańskiej. e-mail: piotr.krzymien@put.poznan.pl

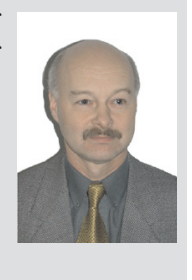

